\title{
Features of Smelting Carbon Ferrochrome in AC and DC Electric Arc Furnace
}

Bishenov S.A. and Pavlov A.V.

NUST “MISiS", Moscow, Russia

\section{Abstract}

The technology of ferrochrome smelting in DC furnaces is described. A comparison is made with the technology of smelting ferrochrome in $A C$ furnaces, the advantages and disadvantages of both technologies are noted. The ways of increasing the production efficiency of ferroalloys in direct current furnaces have been outlined. A promising method of intensification is the use of ore-coal briquettes.

Keywords: carbon ferrochrome, AC and DC electric arc furnace, ore-coal briquettes

\section{Introduction}

Received: 5 February 2019

Accepted: 6 March 2019

Published: 17 March 2019

Publishing services provided by

Knowledge E

(c) Bishenov S.A. and Pavlov

A.V.. This article is distributed

under the terms of the

Commons Attribution License,

which permits unrestricted use

and redistribution provided that

the original author and source

are credited.

Selection and Peer-review under the responsibility of the NIOKR-2018 Conference Committee.
The main volumes of carbon ferrochrome are smelted in ore-reduction electric furnaces of alternating current $(A C)$ furnaces, in which self-baking electrodes are immersed in a mix material, including chrome ore, carbonaceous reducing agent and flux. In round three-electrode electric furnaces of alternating current, the process of chromium ore reduction by carbon is solid-liquid. Oxides are recovered from the slag-ore melt with a carbonaceous reducing agent (coxy, semi-coke, special coke). The reduction of chromium oxide can be represented as follows:

$$
\begin{array}{ll}
2 / 3 \mathrm{Cr}_{2} \mathrm{O}_{3}+18 / 7 \mathrm{C}=4 / 21 \mathrm{Cr}_{7} \mathrm{C}_{3}+2 \mathrm{CO} & \Delta \mathrm{G}^{0}=511128-364,57 \mathrm{~T} \\
& \left(\mathrm{~T}_{\text {beg }}=1402 \mathrm{~K}\right) \\
\mathrm{Cr}_{2} \mathrm{O}_{3}+81 / 23 \mathrm{C}=2 / 23 \mathrm{Cr}_{23} \mathrm{C}_{6}+3 \mathrm{CO} & \Delta \mathrm{G}^{0}=749452-526,47 \mathrm{~T} \\
& \left(\mathrm{~T}_{\text {beg }}=1424 \mathrm{~K}\right)
\end{array}
$$

One of the products of the reduction process is gaseous carbon monoxide, which should freely leave the reaction zone located under the electrodes in the thickness of the charge. This is required for the normal operation of the furnace when using a lumpy chrome charge that has sufficient gas permeability. The use of chromic ore of a large fraction is the main condition for the traditional carbon thermal process, the production 
of ferrochrome in electric furnaces. This is the main drawback of the smelting process of carbon ferrochrome in $A C$ kilns - the need to use a fraction of expensive lumpy ore.

Chrome ores in their mineralogy are represented by chromite. The industrial value of the raw material is determined by the content (about $50 \% \mathrm{Cr}_{2} \mathrm{O}_{3}$ ), at a sufficiently high $\mathrm{Cr}_{2} \mathrm{O}_{3} / \mathrm{FeO}$ ratio (not less than 2.5) and the $\mathrm{SiO}_{2}$ content is not more than $10 \%$ and less than $0.015 \%$ R. The chemical composition of chrome ore is the leading element content, harmful contents impurities and the ratio of chromium oxide to iron oxide, determines the possibility of obtaining carbon ferrochrome with a chromium content of more than $65 \% \mathrm{Cr}$. Along with the chemical composition of chrome-ore raw materials, for the use of chromic ore in the smelting of high-carbon ferrochrome in electric furnaces operating on alternating current, there are size requirements $(10-300 \mathrm{~mm})$, where the fraction less than $10 \mathrm{~mm}$ should not enter into the furnace due to its removal from the working space with exhaust gases.

During the extraction and enrichment of chrome ore, a significant amount of the fine fraction of $\mathrm{Cr}_{2} \mathrm{O}_{3}$ rich in content (less than $10 \mathrm{~mm}$ ) of about $70 \%$ is formed. The ore fines formed in the process of mining and enrichment are not widely used in ferroalloy production and accumulate in the dumps. The use of such chrome-ore raw materials is an urgent task.

The use of chromite ore with a fraction of less than $10 \mathrm{~mm}$ in the production of carbon ferrochrome in $\mathrm{AC}$ electric furnaces requires agglomeration technology and significant capital expenditures.

One of the main directions, according to the experience of a number of countries, the use of small chrome ore for smelting carbon ferrochrome is the use of DC furnaces [1-3]. This electric furnace unit when working with an open arc allows the use of chrome ore fraction less than $10 \mathrm{~mm}$ without preliminary agglomeration. The main parameters of ferrochrome smelting are given in Table 1.

TABLE 1: Parameters of carbon ferrochrome smelting

\section{Indicators}

Transformers power, MVA

Active power, MW

Operating voltage, $\mathrm{V}$

Fractions of chrome-ore raw materials, $\mathrm{mm}$

Specific electrical energy consumption, $\mathrm{kW} \cdot \mathrm{h} / \mathrm{t}$

\begin{tabular}{|c|c|}
\hline \multicolumn{2}{|c|}{ Smelting options } \\
\hline AC & DC \\
\hline $81(3 \times 27)$ & $110(2 \times 55)$ \\
\hline $47-49$ & $45-50$ \\
\hline $300-310$ & $750-850$ \\
\hline $10-300$ & less than 10 \\
\hline $3800-4200$ & $4700-5200$ \\
\hline
\end{tabular}


In DC furnaces, the mechanism of chromium oxide reduction by solid carbon is fundamentally different - in them the ore part of the charge is first melted and then reduced by solid carbon floating on the surface of the slag bath.

However, the process of smelting high-carbon ferrochrome in DC furnaces has drawbacks with regard to the energy efficiency of the process.

In particular, in a DC furnace, the use of only fine chrome ore eliminates the possibility of regulating the carbon content by traditional methods. The only way to reduce the carbon content in the metal to the desired values is to raise the temperature of the entire system inside the furnace. Also, the use of fine chrome ore without preliminary agglomeration increases the recovery process during the smelting of high-carbon ferrochrome in DC furnaces, which affects energy consumption and reduces the service life of the furnace lining.

The method of intensifying the recovery process, and, consequently, increasing the productivity of the unit, is to increase the area of direct contact of the liquid metal with carbon. The easiest way to fulfill such conditions is to use ore coal briquettes.

The main advantage of the DC smelting process is that it is possible to use cheaper chrome ore of small fractions (less than $10 \mathrm{~mm}$ ), which is 10 times cheaper than large lump ore, but this technology requires additional development and improvement.

\section{References}

[1] Geldenhuys I.J. Aspects of dc chromite smelting at mintek-an overview // Proceedings of Thirteenth International ferroalloys congress. - Almaty, Kazakhstan: Infacon - XII. - 9 - 12 July 2013. - P. 149 - 156.

[2] O. Privalov, Ye. Abdulabekov, Zh. Nurmukhanbetov, M. Kospanov, Zh. Mussabekov. Adjustment of idgh carbon ferrochrome composition in DC furnaces // Proceedings of Thirteenth International ferroalloys congress. - Almaty, Kazakhstan: Infacon - XII. - 9 - 12 July 2013. - p. 109 - 114

[3] Shkirmontov A.P., Bishenov S.A., Pavlov A.V. Smelting carbon ferrochrome in DC and AC electric furnaces // Scientific support of technical and technological progress: Collection of articles of the International Scientific and Practical Conference (Orenburg, March 15, 2018). - Ufa. - Aeterna. - 2018. - p. 163 - 166. 